\title{
Relationships between Age, Sex, Laboratory Parameter, and Length of Stay in Patients with Dengue Hemorrhagic Fever
}

\author{
Maria Devi Arianti 1,2), J. Prijambodo3), Hari Wujoso4) \\ 1)Provincial Health Office, Kupang, East Nusa Tenggara \\ ${ }^{2)}$ Masters Program in Family Medicine, Universitas Sebelas Maret \\ 3)Department of Microbiology, Universitas Sebelas Maret \\ 4)Department of Forensic Medicine, Universitas Sebelas Maret
}

\begin{abstract}
Background: Dengue Hemorrhagic Fever (DHF) is an infectious disease caused by dengue virus. Until now, Dengue virus infection remains a health problem in Indonesia. The things which cause problems in DHF case are high mortality rates, diseases spread which areeasily spread, especially affect children. Handling of DHF patients need long of length of stay which has large costs.

Subjects and Method: This was an analytic observational study with cross-sectional design.This study was conducted atDr. Moewardi Hospital, Surakarta, based on medical records. 32 samples were selected using purposive sampling. The independent variables were age, sex, platelet count, hematocrit value, and number of leukocytes. The dependent variable was length of stay. The data were obtained from medical records using Chi square test. Bivariate analysis was used to determine the factors which affected DHF on length of stay using Chi square, Kolmogorov Smirnov, continuing with multiple linear regression analysis.

Results: The age of DHF patients was from 1 year of age to 53 years of age with an average age of $20.07 \pm 13.45$ years. The number of female patients was 15 patients. Platelets level (x 1,000) was 25 for minimum and 308 for maximum. Mean \pm SD platelet was $94.86+67.97$. Hematocrit level was 28 for minimum and 54 for maximum. Mean \pm SD hematocrit was $40.69+6.59$. Leukocytes level ( $\mathrm{x} 1,000$ ) was 1.6 for minimum and 10.8 for maximum. Mean \pm SD leukocytes was $5.50+2.95$. The shortest length of stay was 3 days and the longest was 11 days. Mean \pm SD length of stay was $5.21 \pm$ 1.90 days. The result of multiple linear regression analysis showed a statistically non-significant relationship ( $\mathrm{p}>0.05$ ) between age, sex, platelets, hematocrit, leukocytes, and length of stay.

Conclusion: There is non-significant relationship between age, sex, platelet count, hematocrit value, leukocyte count, and length of stay.
\end{abstract}

Keywords: DHF, length of stay, platelet count, hematocrit value, leukocyte count

\section{Correspondence:}

Maria Devi Arianti. Masters Program in Family Medicine, Universitas Sebelas Maret. Jl. Ir. Sutami 36A, Surakarta 57126, Central Java. Email: ariantidevi88@yahoo.co.id Mobile: o8124612699

\begin{tabular}{l}
\hline BACKGROUND \\
\hline Dengue Hemorrhagic Fever (DHF) is a \\
disease caused by dengue virus transmitted \\
by genus Aedesspmosquitoe. Patients \\
infected by this virus will have various \\
symptoms such as fever and potentially \\
fatal complications as a result of plasma \\
leakage, fluid accumulation, respiratory \\
failure, severe bleeding, and organ dis- \\
orders (WHO, 2014). DHF can occur
\end{tabular}

throughout the year and affect all age groups. This disease is related to environmental conditions and people's behavior (Ministry of Health RI, 2016).

According to WHO data (2014), Dengue Hemorrhagic Fever was first reported in Southeast Asia in 1954 in Philippine, spread to various countries afterwards. Before 1970, there were only 9 countries had dengue outbreaks. Nowadays, DHF is endemic in more than 100 
countries, including Africa, United States, Eastern Mediterranean, Southeast Asia, and Western Pacific which have the highest rates of DHF cases. The number of cases in America, Southeast Asia, and the Western Pacific has passed 1.2 million cases in 2008 and more than 2.3 million cases in 2010. In 2013, there were 2.35 million cases in America, where the 37,687 cases were severe DHF. The develompent of DHF cases at the global level increases, as reported by the World Health Organization (WHO) that from 980 cases in almost 100 countries in 1954-1959 became 1,016,612 cases in almost 60 countries in 2000-2009 (WHO, 2014).

The number of incident cases of DHF in Indonesia from 2011-2017 increased. In 2011, the total number of incident cases of DHF was $27.67 \%$, increased to $37.27 \%$ in 2012, and also increased to $45.85 \%$ in 2013. In 2014, it decreased to $39.80 \%$. In 2015, it increased again to $50.75 \%$ and increased significantly by $78.85 \%$ in 2016 (Ministry of Health RI, 2017).

The increase of DHF cases is a major threat to public health and large economy. The impact of DHF is measured by direct costs, such as the allocation of unplanned funds to overcome DHF outbreaks, medical care costs, such as inpatient and outpatient costs, loss of productive work days due to illness or to take care of sick family members, and indirect costs, such as an increase in household spending to buy mosquito coils and medicines, a decrease in household income due to loss of work days (Sihite et al, 2017).

Based on these items, the risk factors that affect the severity of DHF need further investigation. It is considered as an important thing because it is expected to reduce the severity of the disease. Therefore, it can reduce the length of stay in hospital.

\section{SUBJECTS AND METHOD \\ a. Study Design \\ This study used an analytic observational study with cross-sectional design. This study conducted in Dr. Moewardi Hospital, Surakarta, Central Java in Januari 2019. \\ b. Population and Samples}

The target population in this study was all patients with DHF both children and adults. The accessible population in this study was all patients with DHF at Dr. Moewardi Hospital, Surakarta, between July 2017 to December 2018 who was treated in the children's ward and in the internal medicine ward.

The samplesof this study were all patients with DHF who were treated at Dr. MoewardiHospital, Surakarta. This study used purposive sampling. The samples of this study were patients who met the study criteria from July 2017 to December 2018, so that the number of patients needed was met. The inclusion criteria in this study were patients with DHF of all ages (children and adults), and undergoing inpatient treatment in children's ward and internal medicine ward at Dr. Moewardi Hospital, Surakarta. The exclusion criteria in this study were patients who died while being treated at Dr. Moewardi Hospital, Surakarta, and a DAMA (discharge against medical advice) patient while being treated at Dr. MoewardiHospital, Surakarta.

\section{c. Study Variables}

The independent variables in this study were age, sex, platelet count, hematocrit value, and leukocyte count. The dependent variable in this study was length of stay.

\section{d. Operational Definition of Variables}

Length of Stay. Length of stay was defined as the number of days of inpatient treatment since the first time of being treated until leaving the hospital. Data collection was measured by counting the number of days of inpatient treatment 
based on medical record. The scale of measurement was continuous (day).

Age. Age was one of the factors which affectedsusceptibility to dengue virus infection. All ages could be attacked, although only a few days after birth. Data collection was conducted by looking at medical record data. The scale of measurement was continous (year).

Sex. The sex of the subjects was based on the gender of the individual concerned. Data collection in research carried out by looking at medical record data. The scale of measurement was categorical, namelymale and female.

Platelet Count. Platelet count was the platelet count of the patient after conducting laboratory examination at the first visit. Data collection was carried out by using spectrophotometer by looking at laboratory result recorded in medical record. The measurement scale was continous.

Hematocrit level. Hematocrit level was the patient's hematocrit level after conducting laboratory examination at the first visit. Data collection was carried out by using spectrophotometer by looking at laboratory result recorded in medical record. The measurement scale was continous.

Leukocyte count. Leukocyte count was the number of leukocytes of the patient after conducting laboratory examination at the first visit. Data collection was carried out by using spectrophotometer by looking at laboratory result recorded in medical record. The measurement scale was continous.

\section{e. Study Instruments}

Data collection of length of stay, age, sex, platelet count, hematocrit value, and leukocyte count were collected by looking at medical records and using spectrophoto- meter as a measuring tool to measure platelet count, hematocrit value, and leukocyte count.

\section{f. Data Analysis}

The characteristics of continous data were described in terms of frequency, mean, SD, minimum, and maximum. The characteristics of categorical data samples were described in terms of frequency and percentage. Bivariate analysis which compared the percentage between two or more groups was analyzed by Spearman rank correlation. Multivariate data analysis used linear regression analysis to determine the effects of the factors which affected DHF on length of stay.

\section{g. Research Ethics}

The research ethics in this study were the approval sheet, anonymity, confidentiality, and ethical eligibility. Ethical eligibility in this study was from Research Ethics Committee of Dr. Moewardi Hospital, Surakarta, Number: 799/XII/HREC/2018.

$\frac{\text { RESULT }}{\text { 1. Univariate Analysis }}$

Table 1 shows the variables and each continous data characteristic. Patients age were from 1 year to 53 years of age. Mean \pm SD age was $20.07+13.45$ years of age. The number of female sex was 15 patients. Platelet level (x 1,000) was 25 for minimum and 308 for maximum with the average platelet of $94.86+67.97$. Hematrokit level was 28 for minimum and 54 for maximum. Mean \pm SD hematocrit was $40.69+6.59$. Leukocyte level (x 1,00o) was 1.6 for minimum and 10.8 for maximum. Mean \pm SD leukocyte was $5.50+2.95$. The shortest length of stay was 3 days and the longest was 11 days. Mean \pm SD length of stay was $5.21+1.90$ days. 
Journal of Epidemiology and Public Health (2019), 4(4): 307-313

https://doi.org/10.26911/jepublichealth.2019.04.04.05

Table 1.The basic characteristics of study subjects(continuous data)

\begin{tabular}{lccccc}
\hline Variables & n & Minimum & Maximum & Mean & SD \\
\hline Age & & 1 & 53 & 20.07 & 13.45 \\
Sex & & & & & \\
$\quad$ Female & 15 & & & & \\
$\quad$ Male & 14 & & 308 & 94.86 & 67.97 \\
Platelet & & 25 & 54 & 40.69 & 6.59 \\
Hematocrit & 28 & 10.8 & 5.50 & 2.95 \\
Leukocyte & 1.6 & 11 & 5.21 & 1.90 \\
Length of stay & 3 & & & \\
\hline
\end{tabular}

\section{Bivariate Analysis}

Bivariate analysis in this study aimed to examine the relationship between age, sex, platelet, hematocrit, leukocyte, and length of stay.

Table 2 shows that age $(\mathrm{r}=-0.22 ; \mathrm{p}>$ $0.05)$, sex ( $\mathrm{r}=0.18 ; \mathrm{p}>0.05)$, and platelet

Table 2. The result of bivariate analysis

\begin{tabular}{lcc}
\hline \multirow{2}{*}{ Variables } & \multicolumn{3}{c}{ Length of stay (day) } \\
\cline { 2 - 3 } Age (year) & $\mathbf{r}$ & $\mathbf{p}$ \\
Sex & -0.22 & 0.258 \\
Platelet & 0.18 & 0.347 \\
Hematocrit & 0.03 & 0.873 \\
Leukocyte & 0.01 & 0.969 \\
\hline
\end{tabular}

\section{Multivariate Analysis}

Table 3 shows the resultof linear regression analysis. Multivariate analysis in this study aimed to examine theeffects of age, sex, platelet, hematocrit, leukocyte on length of
( $\mathrm{r}=0.03 ; \mathrm{p}>0.05$ ) had a non-statistically significant relationship on length of stay. Hematocrit ( $\mathrm{r}=0.01 ; \mathrm{p}>0.05)$ and leukocyte $(\mathrm{r}=0.06 ; \mathrm{p}>0.05)$ also had a non-statistically significant relationship on length of stay.

Table 4. The result of multiple linear regression analysis

\begin{tabular}{lcc}
\hline Independent Variables & b & p \\
\hline Age (year) & -0.04 & 0.197 \\
Sex & -0.79 & 0.329 \\
Platelet & 0.01 & 0.879 \\
Hematocrit & 0.05 & 0.450 \\
Leukocyte & -0.06 & 0.680 \\
\hline
\end{tabular}

The result showed a negative and weak relationship between age and length of stay,

the older the patient, the longer the length stay with linear regression. The result of multivariate analysis did not show a significant relationship ( $\mathrm{p}>0.05$ ) between age, sex, platelet, hematocrit, leukocyte on length of stay. of stay. However, it did not show statistically significant result $(b=-0.04 ; p>0.05)$.

Age is one of the factors that affect susceptibility to dengue virus infection. All ages can be attacked, although only a few days after birth. The risk decreases significantly after the age of 12 years (Kasper et 
al., 2017). Age does not show an effect on length of stay because this length of stay can be affected by many things besides age.

The result showed that the younger the age, the longer the length of stay, because it was related to the cooperative level of the patient where the older patients were more cooperative than the younger patients. Therefore, it affected the length of stay, although it was not statistically significant.

\section{The relationship between sex and length of stay}

The result of the study showed a negative and weak relationship between sex and length of stay, where the female tended to stay longer than man. However, it did not show statistically significant result. $(b=-$ $0.79 ; p=0.329$ ).

DHF/DSS disease is more often occur in women than men. In theory, it is believed that women are more at risk of being infected a disease caused by dengue virus, thus obtaining more severe clinical manifestations than men. This is based on the assumption that capillary walls in women are more likely to increase capillary permeability compared to men (Kasper et al., 2017).

Hormone factors are also the reason that women are more often affected by dengue fever. How hormones work is affected by specific protein namely receptor. Glycoprotein hormone receptor, namely follicle stimulating hormone (FSH) and luteinizing hormone (LH) are found in the gonad cell plasma membrane. The activation of FSH and LH which is affected by the hypothalamus can be suppressed by gonadal steroids, so that the estrogen in children is very low. Estrogen affects the accumulation of fat in the body. As a result, the low estrogen in girls causes little leptin produced by fat cells in the body. Leptin is a hormone protein that regulates body weight. Therefore, the girls who tend to have underweight with low immunity will be susceptible to disease because they have low cellular immunity, so that the immune response and immunologic memory are not fully developed (Permatasari et al, 2015).

\section{The relationship between platelet count and length of stay}

The result of the study showed the majority of patients had decreased platelet count. As a result, there was no significant relationship between platelet and length of stay.Therewas a positive and very weak relationship between platelet and length of stay. However, it did not show statistically significant result $(b=0.01 ; p=0.879)$.

The platelet counts decreased to $\leq 100,000 / \mathrm{mm}^{3}$ or less than $1-2$ platelets/ high power field with an average examination carried out on $10 \mathrm{lpb}$. In general, thrombocytopenia occurs before hematocrit increases and temperature drops. Platelet counts of $\leq 100.000 / \mathrm{mm}_{3}$ are usually found between the third and seventh day (Suwandono et al., 2011). Platelet examination needs to be repeated until it is proven that platelet counts are within normal or decreased limits. Examination is carried out first when the patient is suspected of suffering from DHF, if the result is normal, the examination is repeated on the third day, but it is necessary to be repeated every day until the temperature drops. Thrombocytopenia in dengue infection occurs through the mechanism of bone marrow suppression, destruction, and shortening of platelet life span (Nopianto, 2012).

Thrombocytopenia has an important role in the pathogenesis of dengue infection. The platelet count in patients with dengue infection decreased on the third day to the seventh day and reached normally on the eighth or ninth day. Thrombocytopenia on dengue infection occurs through the mechanism of bone marrow suppression, 
platelet destruction, and shortening of platelet life span (Masihor et al, 2013).

\section{The relationship between hema- tocrit and length of stay}

The result of the study showed a positive and very weak relationship between hematocrit and length of stay, where the higher the hematocritof the patient, the longer the patient length of stay. However, it did not show statistically significant result $(b=$ $0.046 ; \mathrm{p}=0.450$ ).

The increase of hematocrit values which describe hemoconcentration is found on DHF, a susceptible indicator of the occurrence of plasma leakage, so the hematocrit examination periodically is necessary to be carried out. In general, a decrease of platelet precedes an increase of hematocrit. Hemoconcentration with an increase in hematocrit $\geq 20 \%$ reflects an increase in capillary permeability and plasma permeation (Hadinegoro, 2006).

Based on a study conducted by Syumarta et al (2014), initial hematocrit levels and clinical degrees of DHF were not significantly related while peak hematocrit levels were related. Therefore, the hematocrit level may not be the dominant initial factor on the pathogenesis of DHF, but it is a continuous variable on the disease.

\section{The relationship between leuko- cyte and length of stay}

The result of the study showed a positive and very weak relationship between leukocyte and length of stay, where the higher the leukocyte level, the longer the patient length of stay. However, it did not show statistically significant result $(b=-0.06$; $\mathrm{p}>0.05$ ). This is possible because leukocyte between patients have almost the same variance, so that it gives non-significant effect on length of stay.

The leukocyte counts were normal, but usually decreased with the dominance of neutrophil cells. Afterwards, in the final phase of fever, the leukocyte counts and neutrophil cells decreased, so that the lymphocyte cells were relatively increased. An increase in the number of atypical lymphocytes or blue plasma lymphocytes was $>4 \%$ in the periphery could be found on the third day to the seventh day. The atypic lymphocyte is a single nucleated cell (mononuclear) with a smooth and slightly solid chromatin structure, and a relatively wide cytoplasm which has dark blue color. Therefore, it is called blue plasma lymphocytes (LPB).

Blue plasma lymphocytes can be found since the third day of heat. It helps in diagnosing DHF. A study in Thailand proves that patients with severe dengue infection have higher percentage of atypical lymphocytes than patients with mild dengue infection (Agus et al, 2011).

Based on the result of leukocyte examination since the first time of being treated in the hospital, patients with severe dengue infection had higher leukocyte count compared with patients with mild dengue infection (Masihor et al, 2013).

AUTHOR CONTRIBUTION
Maria Devi Arianti is the main researcher
who played a role in collecting and pro-
cessing the data of the study. J. Prijambodo
examined the conceptual framework and
methodology of the study. HariWujoso
analyzed the data and interpreted the
results of the analysis.

SOURCE OF RESEARCH FUNDING

This study used independent cost by the main researcher.

\section{CONFLICT OF INTEREST}

$\overline{\text { The researcher does not have any conflict of }}$ interest. 


\section{ACKNOWLEDGEMENTS}

We thank to the party from Dr. Moewardi hospital, Surakarta,and the officers who helped the research and the study subjects who have participated and have been willing to be the study subjects.

\section{REFERENCES}

Agus S, Nurhayati P (2011). Perbandingan nilai diagnostik trombosit, leukosit, antigen NS1, dan antibodi IgM antidengue. Jurnal Indonesian Medical Association. 61:8.

Hadinegoro SRH, Soegijanto S, Wuryadi S, Suroso T (2006). Tatalaksana Demam Berdarah Dengue di Indonesia. Direktorat Jenderal Pengendalian Penyakit dan Penyehatan Lingkungan. Jakarta

Kasper DL, Braunwald, Fauci, et al. (2017). Harrison's Principle of Internal Medicine 19th edition Volume I. New York: McGraw-Hill Medical Publishing Division. 1239.

Kementerian Kesehatan Republik Indonesia (2016). Profil Kesehatan Indonesia 2015. Jakarta.

Kementerian Kesehatan Republik Indonesia (2017). Profil Kesehatan Indonesia 2016. Jakarta.

Masihor JJG, Mantik MFJ, Memah M, Mongan AE (2013). Hubungan jumlah trombosit dan jumlah leukosit pada pasien anak demam berdarah dengue. Jurnal e-Biomedik (eBM). 1:1.

Nopianto H (2012). Faktor-faktor yang berpengaruh terhadap lama rawat inap pada pasien demam berdarah dengue di RSUP Dr. Kariadi Semarang. Retrieved from: http://eprints.undip.ac.id/37550/1/hasri_nopianto_-_laporan_hasil_kti.pdf.

Permatasari DP, Ramaningrum G, Novitasari A (2015). Hubungan status gizi, umur, dan jenis kelamin dengan derajat infeksi dengue pada anak. Jurnal Kedokteran Muhammadiyah. 2(1).

Sihite EW, Mahendradata Y, Baskoro T (2017). Beban biaya penyakit demam berdarah di rumah sakit dan puskesmas. Berita Kedokteran Masyarakat. 33:7.

Syumarta Y, Hanif AM, Rustam E (2014). Hubungan jumlah trombosit, hematokrit, dan hemoglobin denan derajat klinik demam berdarah dengue pada pasien dewasa di RSUP M Djamil Padang. Jurnal Kesehatan Andalas 3(3).

WHO (2014). Dangue And Severe Dengue. From World Health Organization. Retrieved from: Http://Www.Who.Int/Mediacentre/Factsheets/Fs117/E $\mathrm{n} /$. 